\title{
MAKNA SIMBOL-SIMBOL UPARENGGA PADA UPACARA MEKALA-KALAAN DALAM PERKAWINAN UMAT HINDU ETNIS BALI
}

\author{
Oleh : \\ Ni Nyoman Sudiani \\ (E-mail : sudianistah@gmail.com)
}

\begin{abstract}
The aim of this research is to reveal which containe in the uparengga symbols at the makala-kalan ceremony in the wedding of Balinese Hindu so all of the Hindus people can understand the meaning of upakara media in the mekala-kalan ceremony and then Hindus people have their belief to the proses of mekala- kalan ceremony in building the sukhinah new family. As for, there is a question that need to be answered in this research is "What is the meaning of the Uparengga symbols at the Mekala-kalan ceremony in the Wedding of Balinese Hindus?". This research is a qualitative research.

The research result showed that: a) uparengga which is used in makala- kalan ceremony are: (1) Sanggah Surya, (2) tetimpug, (3) tikeh dadakan, (4) white thread, (5) tegen-tegenan, (6) suhun-suhunan, (7) 3 katih (bar) of broomstick, (8) sambuk (gray) kupakan (opened), and (9) merchandise; and $b$ ) the meanings that contain in the uparengga symbols are: (1) Sanggah Surya is part of (nyasa) sthana symbols which the manifest of Sang Hyang Widhi (God), in this case, this is sthananya Dewa Surya, to give enlightenment and life to the both newly wed, (2) Tetimpug has meaning as communication tools by niskala way (the unseen world) to Bhüta Kala and in sakala (real world) to the others people that makala-kalaan ceremony or the wedding ceremony immediately will be held, (3) Tikeh dadakan (small mat), which means of purity prakrti as the base for Purusa in doing the activities, (4) White Thread is the symbol of time constraintand and the distance barrier; (5) Tegen-Tegenan is the symbols of the taking over the responsibility which tend to sekala-niskala, (6) Suhun-Suhunan is the symbol of eagerness to build the sukhinah family by consolidating the eagerness of both bride, (7) 3 katih (bar) of broomstick has meaning of hard worker and the means of gave birth, life and death, (8) Sambuk (gray) kupakan (opened) contain the meaning of the unite of family to build a suhkinah household and every household will face some problems, by this means, every problem should be cope in a good way with common sense, and (9) dagangan (merchandise) consist of meaning, if there is problem that should be discussed or agreed before making the decisions.
\end{abstract}

Keywords: uparengga symbols, mekala-kalaan ceremony, Balinese Hindus wedding 


\section{PENDAHULUAN}

Bilamana umat manusia dapat memenuhi keinginan dan kapan manusia membutuhkan artha, kitab suci Veda telah membagi tahapan masa kehidupan ini menjadi empat tahap, yang disebut dengan Catur Áśrama. Empat tahap masa kehidupan manusia tersebut, seperti Brāhmacāri Āśrama, Gṛhasta Āśrama, Wanaprasta Āśrama, dan Sanyāsa Āśrama. Adapun pemenuhan artha dan kāma yang berlandaskan ajaran dharma dapat dilakukan pada masa kehidupan Gṛhasta Āśrama (masa kehidupan berumah tangga).

Pada tahap masa kehidupan Gŗhasta Áśrama, merupakan perubahan tahap kehidupan dari kehidupan menuntut ilmu menjadi masa kehidupan berumah tangga. Pada tahap masa kehidupan ini dua orang umat manusia mulai mengikatkan dirinya pada sebuah ikatan yang disebut dengan ikatan perkawinan. Sebuah perkawinan tidak terjadi begitu saja, tidak dapat dilakukan hanya oleh dua orang manusia saja, namun untuk mengesahkan perkawinan tersebut harus melalui sebuah prosesi (upacara). Pelaksanaan upacara perkawinan dalam agama Hindu harus berlandaskan tiga kerangka dasar ajaran agama Hindu yaitu Tattwa, Susila, dan Ācāra (upacara). Begitu juga umat Hindu etnis Bali yang berdomisili di Jakarta setiap melaksanakan upacara perkawinan selalu berlandaskan Tattwa, Susila, dan Ācāra (upacara). Sebuah upacara perkawinan Hindu etnis Bali juga harus disaksikan oleh tiga saksi yang disebut dengan tri upasaksi yaitu antara lain dewa saksi, bhūta saksi dan manusa saksi. Namun sampai saat ini dari ketiga landasan tersebut, yang paling menonjol dalam prosesi perkawinan umat Hindu etnis Bali adalah aspek Ācāra (upacara).

Dalam pelaksanaan upacara perkawinan umat Hindu etnis Bali tidak lepas dari penggunaan sarana berupa banten. Banten diyakini sebagai simbolsimbol yang dapat menghubungkan umat manusia dengan Ida Sang Hyang Widhi Wasa, dan sebagai simbol yang dapat menyampaikan keinginan kedua mempelai kehadapan Ida Sang Hyang Widhi Wasa. Sarana banten memang sangat penting artinya di kalangan umat manusia yang menjalankan bhakti marga dan karma marga. 
Hal yang dianggap paling penting dalam menentukan sah tidaknya perkawinan dalam umat Hindu etnis Bali adalah upacara Sarira Samkara (Upacara mekala-kalaan), sehingga bagi mereka yang memiliki kemampuan finansial yang terbatas biasanya cukup hanya sampai pada upacara ini, sedangkan tahapan berikutnya akan dilaksanakan dikemudian hari jika mereka telah memiliki biaya untuk melaksanakannya. Pada upacara mekalakalaan terdapat berbagai nasehat yang diberikan untuk kedua mempelai, namun dalam bentuk simbol- simbol yang dalam konteks penelitian ini disebut uparengga. Tidak semua umat Hindu memahami makna Uparengga pada upacara mekala-kalaan, sehingga terkesan hanya sebagai pelengkap upacara.

Melihat kenyataan ini, dalam artikel ini penulis akan mencoba menggali apakah makna simbol-simbol uparengga pada upacara mekalakalaan, sehingga umat Hindu khususnya yang tinggal di luar Bali memiliki keyakinan terhadap simbol-simbol uparengga yang digunakan pada upacara mekala-kalaan dalam rangka mewujudkan rumah tangga yang sukhinah.

\section{Makna Simbol-simbol Uparengga}

Kata simbol (dalam bahasa Inggris symbol) mengandung arti: untuk sesuatu atau juga menggambarkan sesuatu, khususnya untuk menggambarkan sesuatu yang immaterial, abstrak, suatu idea, kualitas, tanda-tanda suatu obyek, proses dan lain-lain (Titib, 2003, p. 63). Kata simbol berasal dari Bahasa Greek, "sum-balloo" yang mengandung arti "saya bersatu bersamanya", "penyatuan bersama". Apakah yang dapat disatukan bersama dalam simbol itu, di satu pihak adalah bentuk, nilai harfiah di pihak yang lain, kehidupan yang membimbing kita, pengertian atau kesalahpahaman, kesadaran atau ketidaksadaran (Titib, 2003, p. 63).

Ardhendu Sekhar Gosh seperti yang dikutif oleh Titib menyatakan bahwa kata simbol berasal dari kata "symbolon" (dalam bahasa Greek) yang berarti tanda dan dengan tanda itu seseorang mengetahui atau mengambil kesimpulan tentang sesuatu. Di dalam bahasa Sanskerta kata simbol adalah "pratika" yang mengandung arti yang datang ke depan, yang mendekati 
(Titib, 2003, p. 63). Selanjutnya di samping kata pratika di atas, kata simbol juga dapat dijumpai beberapa padanannya dalam bahasa Sanskerta, antara lain: cihnam, lakșaṇam, lingam, samjjãa, pratirūpa, di samping itu dikenal pula dengan istilah: arca, pratima, pratiwimba, nyāsa murti dan lainlain (Titib, 2003, p. 64).

Menurut Yudha Triguna dalam konteks arti simbolisme pada masyarakat Hindu, simbol juga sarat dengan makna status dan peranan. Itulah sebabnya pada masyarakat Hindu di Bali simbol dipandang sebagai identitas individu dan atau kelompok. Lebih lanjut Triguna berpendapat paling tidak ada empat peringkat simbol, yaitu (1) simbol konstruksi yang berbentuk kepercayaan dan biasanya merupakan inti dari agama; (2) Simbol evaluasi berupa penilaian moral yang sarat dengan nilai, norma, dan aturan; (3) simbol kognisi berupa pengetahuan yang dimanfaatkan manusia untuk memperoleh pengetahuan tentang realitas dan keteraturan agar manusia lebih memahami lingkungannya; serta (4) Simbol ekspresi berupa pengungkapan perasaan (Triguna, 2000, p. 35).

Berdasarkan beberapa pendapat tersebut di atas maka dapat disintesakan bahwa simbol adalah segala bentuk, tanda dari suatu obyek dan tindakan yang menggambarkan sesuatu, merujuk sesuatu, dan menyatu dengan sesuatu yang sarat dengan makna status dan peranan. Simbol-simbol keagamaan seperti diuraikan di atas juga berfungsi sebagai sarana untuk memantapkan śraddhā dan bhakti umat Hindu kepada Ida Sang Hyang Widhi Wasa (Tuhan Yang Maha Esa).

Upacara yajña yang dilaksanakan oleh umat Hindu selalu disertakan dengan segala perangkat upacara, sehingga upacara tersebut dapat berjalan dengan lancar, semarak, umat mendapatkan kepuasan (atmanastuti), dan selanjutnya dapat meningkatkan śraddha dan bhakti penyelenggara upacara yajña. Perangkat upakara yang biasa dipergunakan pada setiap upacara Panca Yajña disebut dengan istilah Uparengga. Uparengga berasal dari suku kata 'upa-re dan angga, selanjutnya upa diartikan sebagai perantara, 're' berasal dari kata Raditya (sinar suci) yang dapat diartikan sebagai pancaran sinar sucinya Ida Sang Hyang Widhi Wasa, sedangkan 'angga' dapat 
diartikan sebagai wujud atau merupakan perwujudan Sang Hyang Widhi Wasa. Dengan demikian uparengga dapat diberikan arti bahwa semua bentuk perangkat upacara adalah merupakan simbul perwujudan Ida Sang Hyang Widhi Wasa melalui kekuatan sinar suci-Nya (Sudarsana, 2000, p. 2).

Dengan demikian yang dimaksud dengan simbolis uparengga adalah segala perangkat upacara Panca Yajña yang dipergunakan oleh umat Hindu sebagai perwujudan sinar suci Ida Sang Hyang Widhi Wasa yang merujuk pada makna tertentu sehingga umat yang melaksanakan upacara mendapatkan kebahagiaan dan dapat meningkatkan śraddhā dan bhakti. Dalam konteks penelitian ini simbolis Uparengga yang dimaksud adalah Uparengga yang dipergunakan pada upacara mekala-kalan (metegen-tegenan).

\section{Upacara Mekala-kalaan}

Secara etimologis kata Upacara berasal dari bahasa Sanskerta yang terdiri dari dua kata yaitu: "Upa” yang berarti berhubungan dengan, dan "Cara" yang berasal dari kata "car" berarti gerak yang kemudian mendapatkan akhiran "a" menjadi kata benda berarti "gerakan". Jadi Upacara berarti segala sesuatu yang ada hubungannya dengan gerakan atau kegiatan, atau dalam kata lain, upacara adalah pelaksanaan dari salah satu yajña (Surayin, 1992, p. 8).

Upacara mekala-kalaan bertujuan untuk penyucian diri, upacara ini ditujukan kepada Bhūta Kala. Mekala-kalaan merupakan manifestasi dari kekuatan kama yang memiliki sifat keraksasaan. Kedua pengantin dipersonifikasikan sebagai kekuatan kala dan kali yang disebut kala nareswari (Sudarsana, 2008, p. 44). Upacara mekala-kalaan juga disebut upacara bhūta saksi. Dalam Kitab Mānava Dharmaśāstra disebutkan ada lima macam kurban suci, yaitu:

ahutam ca hutam caiva tathā prahutam eva ca, brāhmyam hutam prāsitam ca pañcayajñān pracakşate

artinya: 
"Mereka menamakan ke lima kurban suci ini juga dengan sebutan ahuta, huta, prahuta, brahma-huta dan prasita" japo 'huto huto homah prahuto bhautiko balih, brāhmyam hutam dvijā gryārca prāśitam piț̣ tarpanam

(Mānavadharmaśāstra, III.74)

artinya:

“Ahuta adalah pengucapan doa dari Veda, huta persembahan homa, prahuta upacara bali yang dihaturkan di atas tanah kepada para bhūta. Brahmahuta yaitu menerima tetap brāhmana secara hormat seolah-olah menghaturkan kepada api yang ada dalam tubuh brāhmana dan prasita adalah persembahan tarpana kepada para pitara" (G. dan T. R. S. Pudja, 2004, p. 110).

Berdasarkan sloka tersebut di atas, maka upacara mekala-kalaan yang ditujukan kepada para bhüta yang dihaturkan di atas tanah termasuk dalam, prahuta.

Sudharta menyebutnya sebagai upacara madengen-dengen (mekalakalaan) dan merupakan bagian yang terpenting dalam rangkaian upacara perkawinan. Pada upacara mekala-kalaan dilakukan simbol pembersihan terhadap kedua mempelai terutama suklaswanita (sperma dan ovum) sebagai bibit dan persaksian ke hadapan Ida Sang Hyang Widhi Wasa, masyarakat serta pejabat pemerintah. Upacara ini dilakukan di pekarangan rumah dekat dapur agar Hyang Agni menyaksikan serta membasmi segala halangan. Pada upacara ini disediakan tikar dadakan yang kecil, dibuat dari daun pandan yang masih muda dan dipegang oleh mempelai wanita yang merupakan perlambang keperawanan mempelai wanita. Pada akhir upacara maka tikar daun pandan tersebut ditusuk oleh mempelai pria dengan sebuah keris yang dihias (Sudharta, 2006, p. 25). Upacara ini merupakan upacara tahap pertama untuk menyucikan badan mempelai dan berhubungan dengan Bhüta Kala. Upacara mekala-kalaan tersebut dipimpin oleh seorang pemangku. 
Uraian tersebut di atas selanjutnya disimpulkan bahwa yang dimaksud dengan upacara mekala-kalaan adalah upacara penyucian yang dilakukan oleh pasangan pengantin yaitu dalam rangka mensucikan sukla dan swanita sehingga kelak dapat melahirkan putra yang suputra, dan diberitahukan kepada Bhūta Kala dan masyarakat setempat dengan memakai berbagai perangkat upakara.

\section{Perkawinan Hindu Etnis Bali}

Perkawinan merupakan upacara atau ritual yang mengantarkan umat manusia memasuki jenjang kehidupan baru, yang dalam ajaran agama Hindu dikenal dengan memasuki masa Grhasta Asrama. Grhasta Asrama adalah jenjang kehidupan ke dua dalam Catur Asrama setelah masa Brahmacari Asrama. Catur Asrama merupakan empat tahapan kehidupan yang dilalui oleh umat manusia pada umumnya. Tahapan Grshasta Asrama dilakukan setelah seseorang dipandang telah memiliki bekal yang cukup, adapun bekal yang dimaksud disini adalah bekal ilmu pengetahuan yang diperoleh pada masa Brahmacari, karena dengan memiliki ilmu pengetahuan seseorang mampu mencari penghidupan sehingga dapat melaksanakan tanggung jawab kepada keluarga.

Pengertian perkawinan dapat dilihat dari sudut pandang agama dan melalui sudut pandang hukum negara. Pengertian perkawinan apabila ditinjau dari bunyi Undang-Undang No 1 Tahun 1974, tepatnya pada pasal 1 disebutkan bahwa perkawinan adalah ikatan lahir-batin antara seorang pria dengan seorang wanita sebagai suami istri dengan tujuan untuk membentuk keluarga (rumah tangga) yang bahagia dan kekal berdasarkan ke-Tuhanan Yang Maha Esa.

Secara etimologi, kata perkawinan dalam bahasa Tamil disebut Thirumanam. "Thirumanam" terdiri dari dua kata yaitu "Thiru" dan "Manam". Kata "Thiru" berarti tentang, berasal dari, atau berhubungan dengan Tuhan, sedangkan kata "Manam" berarti menyatukan. Jadi kata Thirumanam dalam Agama Hindu adalah penyatuan kedua jenis manusia atas kehendak Tuhan Yang Maha Esa (Kobalen, 2004, p. 9). Penyatuan pria dan wanita tersebut akan terwujud pada saat dilangsungkan upacara perkawinan. 
Selanjutnya perkawinan dalam tatanan masyarakat Hindu Bali dikenal dengan ucapan perkawinan, yang memiliki kata sinonim, "mesakapan, "pengantenan", atau "pawiwahan". Kata mesakapan, berasal dari kata "Sakap", mendapat awalan me- dan akhiran -an, kata sakap mengandung arti "menyatu".

Apabila ditinjau dari nilai-nilai luhur ajaran agama Hindu, mesakapan dapat berarti menyatukan lingga dengan yoni, yang dikenal dengan sebutan Ardhanareswari sebagai kekuatan peleburan dosa. Sedangkan kata pengantin berasal dari suku kata "anti" mendapat awalan pe-, sisipan -ng- dan akhiran an, kemudian menjadi "pengantian", kemudian terjadi peraenyawaan huruf vokal menjadilah kata "penganten", yang mengandung arti siap sebagai pengganti tanggung jawab orang tua. Sedangkan kata pawiwahan berasal dari kata "wiwaha", mendapatkan awalan pe- dan akhiran -an, dimana kata pawiwahan tersebut mengandung arti meningkatkan kesucian serta spriritual (Sudarsana, 2008, p. 2).

Berdasarkan kitab Manusmṛti, perkawinan bersifat religius dan obligator karena dikaitkan dengan kewajiban seseorang untuk mempunyai keturunan dan untuk menebus dosa-dosa orang tua dengan melahirkan seorang putra yang berarti "ia yang menyelamatkan arwah orang tuanya dari neraka (put)" (Sudharta, 2006, p. 71). Oleh karena upacara perkawinan dalam ajaran agama Hindu bertujuan untuk menebus atau membayar hutang (rna) kehadapan para leluhur melalui jalan melahirkan anak yang suputra, sehingga upacara perkawinan dalam ajaran agama Hindu tersebut merupakan sebuah yajña.

Upacara perkawinan sebagai salah satu bagian dari Panca Yajña yaitu Manusa Yajña yang dilaksanakan oleh umat Hindu adalah merupakan suatu kewajiban suci yang bersifat religius sehingga merupakan ritual yang disebut Samskara Wiwaha, oleh karena itu upacara perkawinan adalah sakral (Sudarsana, 2008, p. 3). Upacara perkawinan tidak hanya dipertanggungjawabkan kehadapan Hyang Widhi Wasa, akan tetapi juga harus dipertanggungjawabkan secara duniawi kepada pasangan dan kepada kedua 
belah pihak keluarga. Upacara perkawinan juga perlu disaksikan oleh masyarakat sekitar yang bertujuan untuk memberitahukan kepada masyarakat bahwa telah terjadi ikatan lahir-bathin antara seorang laki-laki dengan seorang perempuan menjadi suami-istri secara resmi.

Upacara perkawinan merupakan salah satu Sarira Samskara, yaitu upacara penyucian terhadap tri sarira (stula sarira, suksma sarira dan antahkarana sarira), yang bertujuan untuk menyucikan benih kedua mempelai, yaitu sel spermatozoa (Sukla) yang dimiliki oleh mempelai laki-laki dan sel telur (swanita) yang merupakan benih dari mempelai wanita. Sejak upacara perkawinan itu maka mulai terciptanya calon seorang ibu serta calon seorang ayah dari kedua mempelai, sebagai persiapan akan lahirnya seorang anak. Apabila kedua benih tersebut suci diharapkan dari keduanya dapat lahir anak yang suputra (Sudarsana, 2008, p. 4). Pustaka Manawa Dharma Sastra sloka III.37 menyebutkan:

Daśa pūrvān pūran vamśyan ātmānam caika vimśakam, Brāhmīputrah sukr̦ta krn moca yat yenasah pițrn

Terjemahan

"Seorang anak dari seorang istri yang dikawini secara Brāhmā wiwaha, jika ia melakukan hal-hal yang berguna, ia membebaskan dari dosa-dosa sepuluh tingkat leluhurnya, sepuluh tingkat keturunannya, dan ia sendiri sebagai orang yang kedua puluh satu" (G. dan T. R. S. Pudja, 2004, p. 100).

Menyimak dari isi sloka tersebut di atas, dapat memberikan pengertian bahwa untuk melahirkan seorang anak yang suputra dari suatu perkawinan yang terjadi, maka kedua mempelai terlebih dahulu perlu mengadakan suatu upacara penyucian, agar perkawinan dapat dikatakan sebagai yajña.

Perkawinan merupakan peristiwa suci dan kewajiban bagi umat Hindu, seperti disebutkan dalam Manava Dharmasastra IX.96 sebagai berikut: 
prajānārtham 'striyaḥ ș̣ștāḥ samtānārtham 'ca mānavāh, tasmāt sādāhraṇo dharma śrutau patnyā sahoditah

artinya:

"untuk menjadi ibu, wanita diciptakan dan untuk menjadi ayah, laki-laki diciptakan; upacara keagamaan karena itu ditetapkan dalam Veda untuk dilakukan oleh suami bersama dengan istrinya" (G. dan T. R. S. Pudja, 2004, p. 462).

Kitab suci Veda juga mengamanatkan makna perkawinan sebagai penyatuan suami istri yang tidak dapat dipisahkan dan mampu melahirkan putra yang suputra yang dapat memberikan dan mewujudkan kebahagiaan lahir bathin (Titib, 1996b, p. 216), seperti yang disebutkan dalam mantra berikut:

anrrkșarā rjavah santu panthā yebhih sakhāyo yanti to vareyam, samaryamā sam 'bhago no ninīyātsam jāspatyam • suyamamastu devāh

artinya:

"Ya, para dewata, semoga kehidupan perkawinan kami berbahagia dan tenteram"

Asthūri no gārhapatyāni santu

(Ṛgeda VI.15.19)

artinya:

"Hendaknyalah hubungan suami-istri kami tidak bisa putus berlangsung abadi"

samañjantu viśve devāḥ samāpo hrdayāni nau, sam ' matariśva sam 'dhātā samu deștrī dadhātu nau. 
artinya:

"Semoga semua dewa menyatukan kedua hati; semoga penguasa air menyatukan mereka; semoga Matarisvan, Dhata dan Sarasvati yang agung menyatukan kedua hati itu”.

Sloka-sloka tersebut di atas menunjukkan bahwa perkawinan merupakan upacara yang sangat sakral karena melakukan permohonan kepada para dewa agar menyatukan hati kedua mempelai dan membentuk rumah tangga yang sukhinah.

Mantra R.gveda X.85.42 juga dijumpai di dalam kitab Atharvaveda XIV.1.22 yang menyiratkan tentang makna perkawinan untuk mewujudkan kehidupan dan kebahagiaan bersama dengan putra-putri dan cucu-cucu yang lahir dari perkawinan. Mempelai diamanatkan untuk bergembira dan tinggal dirumah sendiri yang menunjukkan kepada kita seseorang yang telah siap memasuki masa Grhasta (hidup berumah tangga) hendaknya dapat menyiapkan rumah sendiri, tidak tergantung dari orang lain (Titib, 1996c, p. 2).

Lebih jauh I Made Titib menyatakan bahwa makna atau prinsip dasar tujuan perkawinan, seperti ditegaskan dalam kitab-kitab Dharmaśāstra adalah untuk mewujudkan tiga hal yaitu:

1) Dharmasapatti, kedua mempelai secara bersama-sama melaksanakan Dharma yang meliputi semua aktivitas dan kewajiban agama seperti melaksanakan Yajña, sebab didalam Grhastalah Yajña dapat dilaksanakan secara sempurna.

2) Prajā, kedua mempelai mampu melahirkan keturunan (putra-putri) yang akan melanjutkan amanat dan kewajiban pada leluhur. Melalui Yajña dan lahirnya putra yang suputra (berbudhi pekerti) seorang anak akan dapat melunasi hutang jasa kepada leluhur (Pitra Rṇa), kepada Tuhan (Deva Rṇa) dan kepada para guru (Rsi Rṇa). 
3) Rati, kedua mempelai dapat menikmati kepuasan seksual dan kepuasankepuasan lainnya (Artha dan Kāma) yang tidak bertentangan dengan Dharma (Titib, 1996a, pp. 3-4).

Di dalam ajaran Hindu ada 8 jenis perkawinan yaitu: Brhmāvivāha, Daivavivāha, Arsavivāha, Prajāpatyavivāha, Gandharvavivāha, Asuravivāha, Paisacavivāha, Raksasavivāha, dan tiga dari yang terakhir pantang untuk dilakukan dan harus dihindari karena bertentangan dengan ajaran Hindu. Di Bali jenis-jenis perkawinan yang umum dilaksanakan ada 3 yaitu Mapadik/Ngidih, Ngelayat atau Ngerorod, dan Nyentana atau Nyeburin.

Berdasarkan beberapa pendapat tersebut di atas maka dapat disimpulkan bahwa perkawinan adalah penyatuan dua orang manusia yang saling mencintai yaitu laki dan perempuan dalam ikatan lahir dan bathin yang dilangsungkan melalui sebuah upacara sakral dan disaksikan oleh para Bhuta, Manusa dan Dewa, sah secara agama dan hukum negara untuk membentuk rumah tangga yang sukinah dengan tujuan melahirkan anak yang suputra.

\section{METODE PENELITIAN}

Metode yang dipergunakan pada penelitian ini adalah metode penelitian kualitatif. Adapun alasan peneliti menggunakan metode kualitatif adalah karena adanya keinginan peneliti untuk mendeskripsikan pendapat atau persepsi umat Hindu di Jakarta mengenai makna simbol-simbol uparengga pada upacara mekala-kalaan pada perkawinan umat Hindu Etnis Bali, supaya umat ke depannya semakin memiliki keyakinan terhadap simbol-simbol uparengga yang dipergunakan pada saat upacara mekalan-kalaan, sehingga tidak terjadi wacana nak mula keto secara berkelanjutan. Hal itu seperti yang dikatakan oleh Moleong, bahwa penelitian kualitatif adalah penelitian yang bermaksud untuk memahami fenomena tentang apa yang dialami oleh subjek penelitian misalnya perilaku, persepsi, motivasi, tindakan dan lainlain, secara holistik, dan dengan cara deskriptif dalam bentuk kata-kata dan bahasa, pada suatu konteks khusus alamiah dan dengan memanfaatkan berbagai metode alamiah (Moleong, 2010, p. 6). Menurut Stake bahwa penelitian kualitatif sangat bergantung pada interpretasi langsung dari 
peristiwa di lapangan (Stake, 2010, p. 54), sehingga pada penelitian ini juga bergantung pada interpretasi umat Hindu di Jakarta terhadap makna simbol- simbol uparengga yang dipergunakan pada saat upacara mekala-kalaan oleh masyarakat Hindu etnis Bali, sehingga maknanya dapat dipahami oleh umat khususnya umat Hindu di Jakarta.

Adapun data penelitian ini adalah primer dan sekunder, di mana data primer akan digali di lapangan melalui observasi, dokumentasi dan wawancara, sedangkan data sekunder akan diperoleh melalui kepustakaan, selanjutnya sumber data adalah informan, benda dan catatan-catatan (Burhan, 2010, p. 76). Teknik pemilihan informan adalah snowball sampling (Creswell, 2007, p. 125). Pengumpulan data melalui (1) wawancara, yaitu wawancara tidak terstruktur, Creswell berpendapat bahwa wawancara kualitatif, jika tidak terstruktur, dapat benar-benar memberikan peserta kontrol yang cukup besar atas proses wawancara (Creswell, 2007, p. 123); (2) Dokumentasi dengan teknik merekam gambar dan pengumpulan arsip-arsip; dan (3) Observasi, yaitu observasi partisipatif pasif, yaitu peneliti datang di tempat kegiatan penelitian yang diamati, tetapi tidak ikut terlibat dalam kegiatan yang terjadi di tempat penelitian (Sugiyono, 2011, p. 227). Analisis data dilakukan menggunakan model Miles dan Huberman, yaitu data reduction, data display, dan conclusion drawing/verification. Pemeriksaan keabsahan data dilakukan melalui teknik triangulasi.

\section{HASIL PENELITIAN DAN PEMBAHASAN}

Uparengga yang Dipergunakan pada Upacara Makala-kalan dalam Perkawinan Hindu Etnis Bali

Uparengga mekala-kalaan yang dipergunakan dalam upacara perkawinan umat Hindu etnis Bali menurut Ida Pedanda Gede Panji Sogata (wawancara, 11 Nopember 2009), dan juga berdasarkan kepustakaan, antara lain:

1) Sanggah Surya

Sanggah Surya biasanya ditancapkan di halaman rumah dengan posisi menghadap ke barat atau ke selatan, atau berhadap-hadapan dengan calon pengantin. Sanggah Surya biasanya bersifat sementara. 


\section{2) Tetimpug}

Dalam rangkaian upacara mekala-kalaan ada sarana yang dipergunakan yaitu tetimpug yang dibuat dari tiga buah potong bambu yang masingmasing ada ruasnya, yaitu lima ruas atau tujuh ruas. Ketiga potong bambu ini diikat jadi satu kemudian dibakar di atas tungku bata yang dibuat pada saat upacara mekala-kalaan. Ketiga bambu tersebut dibakar sampai terdengar suara letusan sebanyak tiga kali.

3) Tikeh dadakan (tikeh kecil)

Dalam pelaksanaan upacara mekala-kalaan dibuatkan tikeh dadakan. Tikeh dadakan ini diduduki oleh pengantin wanita, sedangkan pengantin pria membawa sebuah keris (Sudarsana, 2008, p. 48).

4) Benang Putih

Dalam pelaksanaan upacara mekala-kalaan dipergunakan benang putih yang kedua ujungnya masing-masing diikatkan pada sebuah cabang pohon dapdap (Sudarsana, 2008, p. 49).

5) Tegen-Tegenan

Dalam upacara mekala-kalaan juga terdapat perangkat tegen-tegenan. Perangkat tegen-tegenan tersebut terdiri dari batang kayu dapdap atau tebu sebagai sanan, sebuah cangkul, dan dibagian depannya digantungkan periuk berisi siut, dan ikan yuyu, sedangkan dibagian belakangnya sebutir buah kelapa (Sudarsana, 2008, p. 51). Tegentegenan ini dipikul oleh pengantin pria pada saat melaksanakan purwa daksina.

6) Suhun-Suhunan (sarana junjungan)

Dalam pelaksanaan upacara mekala-kalaan selain adanya tegentegenan yang dipikul oleh pengantin pria, juga ada suhun-suhunan yang dijunjung oleh pengantin wanita. 
7) Sapu Lidi 3 katih (3 batang)

Upacara mekala-kalaan yang dijalankan oleh kedua pengantin juga menggunakan uparengga berupa sapu lidi sebanyak tiga katih (batang). Sapu lidi ini dipegang oleh pengantin pria sambil berjalan di belakang pengantin wanita. Pada saat kedua pengantin berjalan mengelilingi Sanggah Surya sebanyak tiga kali, pada saat itulah pengantin pria mencemeti pengantin wanita.

8) Sambuk (serabut) kupakan

Sambuk (serabut) yang dibelah tiga, di dalamnya diisi sebutir telor bebek, kemudian dicakup kembali dan diikat dengan benang tri datu (Sudarsana, 2008, p. 61). Pada saat upacara mekala-kalaan berlangsung serabut kelapa itu ditendang oleh kedua pengantin, yang disebut matanjung sambuk, masing- masing sebanyak tiga kali, setelah itu diduduki secara simbolis oleh pengantin wanita.

9) Dagangan (bahan jual beli)

Dagangan merupakan sarana untuk melakukan jual beli oleh kedua pengantin. Dagangan ini digelar pada saat acara makala-kalan yaitu pada saat medagang-dagangan.

Makna Simbol Uparengga pada Upacara Mekala-kalaan dalam Perkawinan Hindu Etnis Bali

Banyak kalangan umat Hindu khususnya umat Hindu etnis Bali yang tinggal di luar Bali dan telah menikah menyatakan bahwa mereka sama sekali tidak mengerti apa yang mereka lakukan pada saat upacara pernikahan dilaksanakan. Hal ini terungkap dari hasil wawancara yang penulis lakukan terhadap beberapa responden atau umat yang berdomisili di Jakarta. sebagian besar dari responden menyatakan bahwa mereka hanya mengikuti apa yang diperintahkan oleh yang memimpin upacara tanpa mengetahui apa makna dari rangkaian upacara yang dilaksanakan. Namun demikian semua responden menyatakan bahwa perkawinan yang mereka lakukan adalah sah karena sudah sesuai dengan hukum agama yang berlaku. 
Oleh karena itu pada artikel ini penulis mencoba untuk menguraikan makna dari simbol-simbol uparengga yang dipakai dalam upacara perkawinan khususnya pada saat upacara mekala-kalaan, yang penulis peroleh selama melakukan penelitian baik melalui wawancara langsung maupun melalui berbagai literatur.

Peralatan (uparengga) yang dipergunakan pada saat upacara makalakalaan adalah merupakan simbol (nyasa). Adapun makna simbolsimbol uparengga yang dipergunakan dalam upacara mekala-kalaan tersebut adalah sebagai berikut:

\section{1) Sanggah Surya}

Menurut Ida Pedanda Gede Panji Sogata (wawancara, 11 Nopember 2009) bahwa Sanggah Surya yang ditancapkan di halaman rumah dengan posisi menghadap ke barat atau ke selatan, atau berhadap-hadapan dengan calon pengantin yang sifatnya sementara merupakan simbol (nyasa) sthana manifestasi Sang Hyang Widhi, dalam hal ini adalah merupakan sthananya Dewa Surya, hal senada juga dapat ditemukan dalam buku yang ditulis oleh Sudarsana, yang menyebutkan bahwa yang berstahana di Sanggah Surya juga Sang Hyang Smarajaya bersama Sang Hyang Smara Ratih (Sudarsana, 2008, p. 47).

Berdasarkan pendapat tersebut di atas maka dapat disimpulkan bahwa makna Sanggah Surya adalah merupakan sthana Ida Sang Hyang Widhi Wasa dalam hal ini adalah Dewa Surya yang menyaksikan upacara mekalakalaan yang dilangsungkan oleh kedua mempelai agar perkawinan tersebut menjadi sebuah kehidupan baru yang harmonis. Dewa Surya adalah dewa kehidupan, surya atau matahari adalah sumber energi yang dibutuhkan oleh setiap mahluk di dunia ini, kehidupan tidak akan terjadi tanpa adanya matahari. Hal tersebut tercantum dalam kitab Upanisad, yaitu Chandogya Upanisad III.19.3, "...ketika matahari terlahir, kegaduhan dan teriakan dan sebagai juga semua mahluk dan semua nafsu muncul...” (Radhakrishnan, 1953, p. 466). Bunyi mantra tersebut bermakna bahwa dengan adanya sinar matahari maka kehidupan di dunia ini dapat berlangsung. Matahari juga adalah sebagai 
penerang jagat raya ini, sehingga di Bali Pandita disebut sebagai surya yaitu sosok yang memberikan pencerahan kepada umat. Dengan demikian dapat dikatakan bahwa Sanggah Surya bermakna melalui upacara mekala-kalaan kedua jiwa pengantin mendapatkan pencerahan, dilenyapkan segala kegelapan, keangkuhan jiwa sehingga dapat melaksanakan kehidupan berumah tangga dengan damai. Pandita di Bali disebut sebagai surya,

\section{2) Tetimpug}

Menurut Ida Pedanda Gede Panji Rai Sogata (wawancara, 25 Oktober 2009) tetimpug berfungsi sebagai alat komunikasi baik secara niskala maupun secara sekala. Secara niskala tetimpug berfungsi untuk memberitahukan kepada Bhūta Kala yang akan mendapat persembahan bahwa upacara mekala-kalaan segera dimulai. Secara sekala tetimpug juga mempunyai fungsi untuk memberitahukan kepada warga sekitar bahwa upacara mekala-kalaan segera dimulai.

Dalam konteks penelitian ini dapat dikatakan bahwa tetimpug di dalam upacara perkawinan memiliki makna sebagai alat komunikasi secara sekala dan niskala. Alat komunikasi secara niskala adalah memberitahukan kepada Bhūta Kala dan secara sekala adalah untuk memberitahukan kepada umat sekitar bahwa ada pasangan manusia yang akan melangsungkan upacara mekala-kalaan atau upacara perkawinan, dan upacara tersebut akan segera dimulai. Selain itu, kenapa bambu yang dipilih adalah bambu yang memiliki ruas, bukan bambu yang tanpa ruas? Apabila batang bambu memiliki lebih dari satu ruas itu berarti bahwa batang bambu tersebut adalah tertutup, sehingga pada saat kena panas akan mengeluarkan suara ledakan. Itu bermakna bahwa seseorang yang telah mampu menutup atau mengendalikan indriya maka akan mampu menerima pencerahan (panas api untuk membakar bambu), dan orang yang sudah tercerahkan maka omongannya, suaranya, nasehatnya akan didengar dan dipercaya oleh umat, dan juga didengar oleh para Bhüta Kala. Kita sering mendengar istilah "tong kosong nyaring bunyinya”, begitu pula bambu yang tidak tertutup apabila dipukul suaranya nyaring, namun 
bila dibakar tidak akan menimbulkan suara ledakan, berbeda halnya dengan bambu yang memiliki ruas apabila dipukul suaranya tidak nyaring, akan tetapi sekali bersuara maka akan meledak dan didengar sampai jauh.

Lima ruas berarti orang yang telah mampu memahami hakekat Brahman, Atman, Karmaphala, Punarbhawa dan moksa, sedangkan tujuh ruas bermakna sudah mampu memahami tentang tujuh kegelapan (Sapta Timira) yang menyebabkan malapetaka. Selanjutnya ketiga bambu tersebut diikat menjadi satu bermakna bahwa dasar orang memahami makna Brahman, Atman, Karmaphala, Punarbhawa dan Moksa dengan baik adalah karena telah mampu mensucikan pikiran, ucapan dan tindakan dalam kehidupan seharihari. Begitu pula karena telah mampu mensucikan pikiran, ucapan dan tindakan maka orang tersebut akhirnya mampu menghindari diri dari tujuh kegelapan tersebut. Oleh karena itulah orang yang telah memahami makna ajaran agama Hindu dengan baik yang dipilih untuk menyampaikan pesan kepada para Bhūta Kala dan umat manusia tentang adanya upacara perkawinan, karena orang seperti itu dapat dipercaya.

3) Tikeh dadakan (tikeh kecil)

Tikeh dadakan (tikar kecil) ini memiliki makna sebagai simbol Pradana atau Prakrti. Pada saat upacara mekala-kalaan berlangsung maka tikeh dadakan akan dirobek dengan keris yang dipegang oleh pengantin pria. Keris memiliki makna purusa. Hal ini menurut bapak I Ketut Bantas (wawancara 17 Oktober 2009) dan Ida Pedanda Gede Panji Rai Sogata (wawancara 25 Oktober 2009) memiliki makna bertemunya unsur Purusa dengan unsur Pradana (bertemunya Lingga dengan Yoni).

Berdasarkan pendapat di atas dapat penulis simpulkan bahwa makna tikeh dadakan (tikar kecil) adalah sebagai kesucian Yoni atau Prakrti, sedangkan makna keris adalah sebagai kekuatan Purusa. Dengan bersatunya Purusa dan Prakrti maka akan terjadi penciptaan, seperti disebutkan dalam filsafat Samkhya yaitu bertemunya unsur Purusa dengan unsur Prakrti maka akan terjadi evolusi. Begitu pula di dalam sebuah perkawinan, bersatunya atau bertemunya seorang pria dengan seorang wanita diharapkan akan lahir anak-anak yang suputra. Tikeh (tikar) juga memiliki fungsi sebagai alas, yaitu 
alas untuk berpijak, alas untuk beraktivitas dan begitu pula menurut ajaran Samhkya bahwa Prakrti adalah sebagai alas bagi Purusa untuk melakukan aktivitas, yaitu menikmati dunia ini, dan memperbaiki karma. Tanpa Prakrti maka Purusa tidak mampu menikmati duniawi dan tidak mampu memperbaiki karma. Begitu pula seorang pria bertemu dengan wanita adalah untuk menikmati duniawi ini. Dengan demikian makna tikeh dadakan adalah kesucian Prakrti sebagai alas bagi Purusa untuk melakukan aktivitas.

\section{4) Benang Putih}

Benang putih juga dipergunakan pada upacara mekala-kalaan. Pada saat upacara mekala-kalaan berlangsung kedua pengantin melewati atau memutus benang tersebut sebanyak tiga kali. Menurut Ida Pedanda Gede Panji Rai Sogata (wawancara, 25 Oktober 2009) memutuskan benang oleh pengantin memiliki makna perubahan masa yaitu dari masa brahmacarya ke masa grhasta. Sedangkan menurut bapak I Made Lanus (wawancara, 31 Oktober 2009) memutuskan benang bermakna putusnya segala hubungan dan keterikatan yang dimiliki oleh kedua pengantin dengan orang lain di masa yang lalu.

Berdasarkan pendapat tersebut maka benang putih memiliki makna sebagai pembatas, yaitu pembatas waktu, dan pembatas jarak. Pembatas waktu maksudnya adalah sebagai batas antara waktu masih muda (lajang) dengan waktu hidup berumah tangga. Pada waktu hidup lajang (brahmacari) tidak banyak kewajiban yang dimiliki, namun setelah hidup berumah tangga (g̣̣hasta) maka ada empat kewajiban yang harus dipenuhi, antara lain: (1) melaksanakan upacara yajña, (2) merawat orang tua, (3) melaksanakan Rsi Yajña (berdana punia kepada pandita), dan (4) menjamu tamu. Inilah yang membedakan antara masa brahmacari dengan masa grhasta.

Sedangkan pembatas jarak bermakna bahwa pada saat hidup lajang tidak ada jarak untuk bergaul, setiap orang boleh bergaul atau berteman dengan siapa saja, namun setelah hidup berumah tangga maka tidak memiliki kebebasan untuk bergaul dengan setiap orang, karena sudah seharusnya 
memiliki jarak hubungan dengan lawan jenis. Seorang istri hendaknya mengambil jarak hubungan dengan pria lain, begitu pula sebaliknya. Pembatas tersebut bersifat suci atau positif sehingga warna benang yang dipergunakan adalah putih.

\section{5) Tegen-Tegenan}

Dalam upacara mekala-kalaan juga terdapat perangkat tegen-tegenan. Perangkat tegen-tegenan tersebut terdiri dari batang kayu dapdap atau tebu sebagai sanan, sebuah cangkul, dan bagian depannya digantungkan periuk berisi siut, dan ikan yuyu/kepiting, sedangkan dibagian belakangnya sebutir buah kelapa.

Menurut bapak I Made Kartika (wawancara, 25 Oktober 2009) makna mategen-tegenan adalah sebagai simbol bahwa yang bertanggung jawab dalam menghidupi keluarga adalah suami, walaupun kelak istrinya juga ikut bekerja, tapi beban tersebut tetap ada pada suami dan suami juga bertugas untuk membimbing istrinya. Selain itu menurut bapak Made Lanus (wawancara, 31 Oktober 2009) makna upacara metegen-tegenan adalah untuk mengingatkan kepada pasangan pengantin bahwa untuk mencari penghidupan maka manusia harus mengolah bumi ini dan manusia harus tekun bekerja. Hal senada juga disampaikan oleh bapak I Nengah Dana (wawancara, 11 Oktober 2009) bahwa mategen-tegenan adalah merupakan sebuah nasehat kepada kedua pengantin, setelah berumah tangga harus bekerja keras, karena tugas seorang kepala rumah tangga sangat berat, bahkan lebih berat dari orang yang melaksanakan sukla brahmacari.

Tegenan (tetegenan) berarti beban berat, seperti negen (memikul) sanggah (memikul tanggung jawab terhadap sanggah). Berdasarkan arti tegenan dan pendapat di atas maka dapat disimpulkan bahwa makna tegentegenan adalah merupakan sebuah nasehat orang tua kepada anaknya bahwa menjalani hidup berumah tangga tidaklah mudah, karena sejak mulai berumah tangga seorang anak harus mengambil alih tugas dan tanggung jawab orang tua, baik tanggung jawab beragama atau terhadap leluhur maupun tanggung jawab untuk bermasyarakat. Begitu pula suami sebagai 
kepala rumah tangga bertanggung jawab untuk melindungi dan menghidupi anak, istri dan orang tua, sehingga seorang kepala rumah tangga harus memacu diri dan istrinya untuk bekerja keras.

6) Suhun-Suhunan (sarana junjungan)

Dalam pelaksanaan upacara mekala-kalaan selain adanya tegentegenan yang dipikul oleh pengantin pria, juga ada suhun-suhunan yang dijunjung oleh pengantin wanita. Menurut Ida Pandita Rai Sogata dan juga berdasarkan kajian pustaka yaitu buku makna upacara perkawinan Hindu (Sudarsana, 2008, p. 53) menyebutkan sarana yang terdapat pada suhunsuhunan adalah sebagai berikut:

\section{a. Penyegjeg}

Penyegjeg adalah simbol permohonan kehadapan Sang Hyang Widhi supaya sang pengantin dianugrahkan perilaku yang bersifat jujur, bertindak selalu berdasarkan suara budhinya, karena mulai terjun untuk bermasyarakat. Adapun isi penyegjeg tersebut terdiri dari: (1) Beras, benang, tingkih, pangi, porosan (eteh-eteh tetukon), (2) Tunas kelapa (pujer), (3) Tunas pohon pinang, (4) Pohon keladi, (5) Pohon kunyit, (6) Pohon endong.

Menurut Ida Pedanda Gede Panji Rai Sogata (wawancara, 25 Oktober 2009) berdasarkan isi penyegjeg yaitu pohon-pohonan yang cepat tumbuh maka makna yang terkandung di dalamnya adalah merupakan suatu permohonan agar rumah tangga pasangan pengantin cepat mendapatkan keturunan. Sedangkan menurut bapak I Made Lanus (wawancara, 31 Oktober 2009) pepohonan yang terdapat pada penyegjeg selanjutnya akan ditanam oleh kedua pengantin, adapun makna yang terkandung di dalamnya adalah untuk memakmurkan rumah tangga/negara dimulai dari pertanian, dari pertanian akan menumbuhkan sandang, pangan, dan papan.

Kata penyegjeg berasal dari kata jegjeg yang artinya berdiri tegak, lalu mendapat awalan pe menjadi penyegjeg yang artinya yang membuat 
berdiri tegak. Berdasarkan sumber kepustakaan dan hasil wawancara, dapat disimpulkan penyegjeg bermakna segala sesuatu yang dapat membuat berdiri tegaknya suatu rumah tangga, yaitu sandang, papan dan pangan.

\section{b. Penegteg}

Yajña yang termasuk suhun-suhunan di samping penyegjeg, juga ada lagi yaitu penegteg. Adapun cara merangkai penegteg adalah sebuah bakul di dalamnya berisi sebuah nasi tumpeng, berisi jajan, pisang, tebu, buah-buahan, peras, tulung sayut, canang burat wangi, lenga wangi, berisi banten danan, penyeneng, dan sampian naga sari. Adapun makna dari simbol-simbol yang terdapat pada penegteg tersebut adalah:

Om Sang Hyang Widhi, kami sepasang pengantin memohon anugrah$\mathrm{Mu}$, berikanlah kami pikiran yang cemerlang, teguhkanlah iman kami, seperti seteguh gunung, serta memiliki semangat dalam menghadapi kehidupan. Berikanlah kami sinar welas asih-Mu agar menjadi kedamaian seluas samudra sehingga hubungan kami senantiasa menemukan keharmonisan. Berikanlah kami ketentraman sesuai karma kami (Sudarsana, 2008, p. 60).

Penegteg berasal dari kata tegteg yang artinya kuat, sadar, tetap, dan mantap, lalu mendapat awalan pe menjadi penegteg artinya yang membuat menjadi sadar, tetap, dan mantap. Kesimpulan dari makna penegteg adalah segala sesuatu yang dapat membuat menjadi sadar, tetap dan mantap dalam menjalani hidup berumah tangga.

Kesimpulan dari makna suhun-suhunan berdasarkan isinya antara yaitu penyegjeg dan penegteg adalah bahwa sebagai pasangan pengantin harus memiliki sesuatu yang dapat membuat rumah tangga menjadi tegak berdiri atau dapat mewujudkan rumah tangga yang harmonis yaitu memiliki sandang, pangan dan papan, oleh karena itu untuk memenuhi ketiga hal tersebut maka pasangan pengantin harus menetapkan diri, memantapkan diri dengan jalan menyatukan keinginan, ide dan tujuan agar 
dapat mencapai ketiga hal tersebut. Hal tersebut juga dapat dilihat dari puja penegteg/penyegjeg, seperti:

Om, Na, Ma, Si, Wa, Ya, pekulun Sang Hyang Śiwa Raditya, Sang Hyang Wulan lintang Tranggana, makadi Sang Hyang Saraswati, Bagawan Penyarikan, manusanira aminta sih, apan ipun wus tinugraha de Sang Hyang Tri Semaya mapetemon karma, mangké ipun amelaku panyegjeg muah penegteg ikang Tri Pramana satunggal lanang kalawan wadon, ameriha pada urip muang matemahan trepti paripurna. Om dirgahayu astu tatastu astu ya namah suaha (Puja daha) (Sudarsana, 2008, p. 60).

7) Sapu Lidi 3 katih (3 batang)

Upacara mekala-kalaan yang dijalankan oleh kedua pengantin juga menggunakan uparengga berupa sapu lidi sebanyak tiga katih (batang). Sapu lidi ini dipegang oleh pengantin pria sambil berjalan di belakang pengantin wanita. Pada saat kedua pengantin berjalan mengelilingi Sanggah Surya sebanyak tiga kali, pada saat itulah pengantin pria mencemeti pengantin wanita. Menurut bapak I Nengah Dana (wawancara, 11 Oktober 2009) makna dari simbol tersebut adalah pengantin pria memberi semangat kepada pengantin wanita agar dalam mengarungi kehidupan berumah tangga selalu bekerja keras untuk menghidupi seluruh keluarga. Di dalam kitab suci Mānava Dharmaśāstra disebutkan bahwa masa hidup berumah tangga merupakan masa yang paling berat, karena seorang grhastin selain menghidupi anak, istrinya juga harus menghidupi orang tua, sanyasin, tamu, dan melaksanakan Panca Yajña. Karena itu golongan kepala rumah tangga disebut sebagai golongan yang terutama. Beberapa sloka yang menyebutkan hal tersebut, antara lain:

yathā vāyum samāśritya vartante sarva jantavah, tathā grhasthamāśrama śritya vartante sarva āśramah

(Mānavadharmaśāsta, III.77).

artinya: 
"Sebagai halnya seluruh mahluk hidup dengan menerima bantuan dari udara demikian pulalah anggota dari seluruh golongan dapat hidup dengan menerima bantuannya dari kepala rumah tangga" (G. dan T. R. S. Pudja, 2004, p. 110).

yasmātra yo 'pyāśramino jūānenānannena

cānvaham, grhasthenaiva dhāryante tasmāj

jyeşthāśramo grhī

(Mānavadharmaśāsta, III. 78).

Artinya:

"Karena orang-orang dari ketiga golongan lainnya setiap harinya dibantu oleh kepala rumah tangga dengan pemberian pengetahuan suci dan makanan, oleh karenanya golongan kepala rumah tangga adalah golongan yang terutama” (G. dan T. R. S. Pudja, 2004, p. 111).

ŗşayah pitaro devā bhūtānn atithayas tatā, āśāsate kutumbibhy astebhyah kāryam vijānatā

(Mānavadharmaśāsta, III.80).

artinya:

"Para ŗşi, para leluhur, para dewa, para bhüta dan para tamu meminta persembahan dan pemberian kepada kepala rumah tangga, oleh karena itu yang tahu hukumnya harus memberikan kepada mereka apa yang sesuai untuk mereka masing-masing” (G. dan T. R. S. Pudja, 2004, p. 111).

Berdasarkan sloka tersebut di atas, dapat diketahui bahwa kedudukan sebagai kepala rumah tangga amat berat, maka dari itu seorang kepala rumah 
tangga dituntut untuk selalu bekerja keras agar dapat memenuhi kewajibannya tersebut.

Selain itu menurut bapak I Made Lanus (wawancara, 31 Oktober 2009) seorang istri juga tidak disalahkan untuk ikut membantu suami bekerja mencari nafkah, sehingga pada saat upacara mekala-kalaan pengantin pria mencemeti pengantin wanita dengan menggunakan sapu lidi, yang memiliki makna memberi semangat kepada pengantin wanita untuk selalu bekerja keras.

Berdasarkan pendapat narasumber maka penulis mengambil kesimpulan bahwa makna dari tiga sapu lidi adalah semangat untuk bekerja keras dalam menjalani kehidupan berumah tangga yang didasarkan oleh Tri Kaya Parisudha. Tiga sapu lidi juga bermakna lahir, hidup dan mati. Setiap manusia yang lahir maka kematian adalah sudah pasti seperti bunyi sloka pada Bhagavadgita II.27,

"sesungguhnya setiap yang lahir, kematian adalah pasti..." (G. Pudja, 2004, p. 48). Sebelum kelahiran menunggu mati maka setiap orang harus mengisi hidup ini dengan cara bekerja keras sehingga hidup ini tidak sia-sia, hal itu disebutkan dalam Bhagavadgita III.8, "Bekerjalah seperti yang telah ditentukan, sebab berbuat lebih baik dari pada tidak berbuat, dan bahkan tubuhpun tak akan berhasil terpelihara tanpa berkarya" (G. Pudja, 2004, p. 83). Tuhan juga tidak pernah berhenti untuk bekerja, seperti disebutkan oleh sloka Bhagavadgita III.22, ”tak ada pekerjaan yang harus Kukerjakan di ketiga dunia ini, atau yang belum Aku capai, wahai Arjuna, tetapi Aku tetap sibuk dalam kegiatan kerja" (G. Pudja, 2004, p. 91). Berdasarkan kedua sloka di atas maka sudah seharusnya seperti itulah manusia mengisi kehidupannya, sebab tanpa bergerak atau bekerja maka tubuh akan cepat rusak.

8) Sambuk (serabut) kupakan (dibuka)

Dalam upacara mekala-kalaan juga menggunakan sambuk (serabut) yang dibelah tiga, di dalamnya diisi sebutir telor bebek, kemudian dicakup kembali dan diikat dengan benang tri datu. Pada saat upacara mekala-kalaan berlangsung serabut kelapa itu ditendang oleh kedua pengantin, yang disebut matanjung sambuk, masing-masing sebanyak tiga kali, 
setelah itu diduduki secara simbolis oleh pengantin wanita. Menurut Ida Pedanda Gede Panji Sogata (wawancara, 25 Oktober 2009), adapun makna dari upacara metanjung sambuk tersebut adalah bahwa di dalam menjalani kehidupan berumah tangga senantiasa ada rintangan yang menghadang. Begitu pula suatu saat akan ada perselisihan, namun hendaknya semua itu harus disikapi dengan sabar dan masing-masing harus menyadari kesalahan, dan masing-masing harus memiliki tekad untuk kembali mempertahankan ikatan perkawinan yang telah disepakati bersama. Di samping itu adanya telor di dalam serabut mengandung makna sang pengantin memohon kehadapan Sang Hyang Widhi agar cepat mendapat keturunan.

Kesimpulan dari makna dari sambuk/serabut yang dibelah tiga selanjutnya disatukan kembali menggunakan benang tri datu adalah bahwa perkawinan merupakan penyatuan dari tiga pihak yang tadinya terpisah yaitu keluarga pria, keluarga wanita dan jiwa kedua pasangan itu sendiri menjadi satu kesatuan keluarga yang utuh. Benang Tri Datu merupakan simbol Brahma, Wisnu dan Iswara yaitu pencipta, pemelihara dan pelebur, itu berarti pasangan baru hendaknya mampu menciptakan, memelihara hal-hal yang baik dan melebur segala hal yang buruk seperti perbedaan sehingga terwujud keluarga yang utuh dan harmonis. Serabut ditendang dan diduduki oleh istri bermakna bahwa setiap rumah tangga kadang kala terjadi permasalahan dan untuk mengatasi masalah tersebut maka sang istri harus mampu mengendalikan diri karena seperti ajaran. Samhkya wanita selalu dipengaruhi oleh perasaan dan sedikit menggunakan akal, oleh karena itu untuk menyelesaikan masalah istri harus menenangkan diri sehingga masalah dapat diatasi dan selanjutnya dapat memperoleh kebahagiaan yaitu melahirkan keturunan yang utama.

9) Dagangan (bahan jual beli)

Medagang-dagangan terdapat dalam rangkaian upacara mekalakalaan. Medagang-dagangan dilakukan oleh pengantin pria dengan pengantin wanita. Di dalam medagang-dagangan terdapat aktifitas tawar-menawar dan selanjutnya jual beli. Akhir dari medagang-dagangan merobek tikeh dadakan. 
Makna dari simbol medagang-dagangan menurut Ida Pedanda Gede Panji Rai Sogata adalah kesepakatan, yaitu kelak setelah berumah tangga segala sesuatu harus diputuskan dengan musyawarah mufakat. Baik suami maupun istri harus menghilangkan atau menekan egonya supaya kesepakatan atau musyawarah mufakat dapat diwujudkan. Medagang-dagangan menurut bapak I Made Lanus (wawancara,31 Oktober 2009) sebagai adalah merupakan gambaran kehidupan rumah tangga. Untuk dapat mensejahterakan keluarga segala cara harus dilakukan yang salah satunya adalah berjualan.

Dari uraian tersebut di atas kesimpulan penulis mengenai makna medagang-dagangan adalah sebuah nasehat kepada kedua pengantin jika kelak membentuk ikatan suami istri maka segala sesuatu sebaiknya dimusyawarahkan terlebih dahulu sebelum mengambil suatu keputusan. Baik suami ataupun istri harus pintar-pintar mengendalikan diri, bersedia saling mengalah dan tidak mementingkan ego masing-masing, sehingga dengan demikian kesepakatan akan terwujud dan apapun yang menjadi tujuan dari perkawinan tersebut akan tercapai. Dalam medagang-dagangan tersebut ada dagangan atau barang yang dijual, hal itu bermakna adanya sesuatu masalah yang harus didiskusikan sebelum diambil suatu keputusan sehingga kehidupan rumah tangga menjadi harmonis atau sukhinah.

\section{KESIMPULAN}

Kesimpulan yang diperoleh dari hasil penelitian tersebut adalah sebagai berikut:

a. Uparengga yang dipergunakan pada Upacara Mekala-kalaan antara lain:

(1) Sanggah Surya, (2) tetimpug, (3) Tikeh dadakan (tikeh kecil), (4) benang putih, (5) tegen-tegenan, (6) suhun-suhunan (sarana junjugan, (7) sapu lidi tiga katih (3 batang), (8) sambuk (serabut) kupakan, dan (9) dagangan.

b. Makna simbol-simbol Uperangga pada Upacara mekala-kalaan dalam Perkawinan Hindu Etnis Bali

1) Sanggah Surya: Sanggah Surya bermakna sthana Ida Sanghyang Widhi Wasa dalam hal ini adalah Dewa Surya yang menyaksikan 
upacara mekala-kalaan yang dilangsungkan oleh kedua mempelai agar perkawinan tersebut menjadi kehidupan baru yang harmonis. Dewa Surya adalah dewa kehidupan, surya atau matahari adalah sumber energi yang dibutuhkan oleh setiap mahluk di dunia ini, kehidupan tidak akan terjadi tanpa adanya matahari. Matahari juga adalah sebagai penerang, hal itu bermakna bahwa melalui upacara makalan-kalan kedua jiwa pengantin mendapatkan pencerahan, dilenyapkan segala kegelapan, keangkuhan jiwa sehingga dapat melaksanakan kehidupan berumah tangga dengan damai.

2) Tetimpug: tetimpug memiliki makna sebagai alat komunikasi secara sekala dan niskala. Alat komunikasi secara niskala adalah memberitahukan kepada Bhūta Kala dan secara sekala adalah unutk memberitahukan kepada umat sekitar bahwa upacara mekala-kalaan atau upacara perkawinan segera dimulai.

3) Tikeh dadakan: makna tikeh dadakan adalah sebagai kesucian Yoni atau Prakrti, sedangkan makna keris adalah sebagai kekuatan Purusa. Dengan bersatunya Purusa dan Prakrti maka akan terjadi penciptaan, seperti disebutkan dalam filsafat Samkhya yaitu bertemunya unsur Purusa dengan unsur Prakrti maka akan terjadi evolusi. Begitu pula di dalam sebuah perkawinan, bersatunya atau bertemunya seorang pria dengan seorang wanita diharapkan akan lahir anak-anak yang suputra. Dengan demikian makna tikeh dadakan adalah kesucian Prakrti sebagai alas untuk Purusa dapat melakukan aktivitas.

4) Benang putih: benang putih memiliki makna sebagai pembatas, yaitu pembatas waktu, dan pembatas jarak.

5) Tegen-tegenan: makna tegen-tegenan adalah nasehat orang tua kepada anaknya bahwa menjalani hidup berumah tangga tidaklah mudah, karena sejak mulai berumah tangga seorang anak harus mengambil alih tugas dan tanggung jawab orang tua, baik tanggung jawab beragama atau terhadap leluhur maupun tanggung jawab untuk bermasyarakat juga bertanggung jawab untuk melindungi dan menghidupi anak, 
istri dan orang tua, sehingga seorang kepala rumah tangga harus memacu diri dan istrinya untuk bekerja keras.

6) Suhun-suhunan: makna suhun-suhunan berdasarkan isinya yaitu: penyegjeg dan penegteg adalah bahwa sebagai pasangan pengantin harus memiliki sesuatu yang dapat membuat rumah tangga menjadi tegak berdiri atau dapat mewujudkan rumah tangga yang harmonis yaitu memiliki sandang, pangan dan papan, oleh karena itu untuk memenuhi ketiga hal tersebut maka pasangan pengantin harus menetapkan diri, memantapkan diri dengan jalan menyatukan keinginan, ide dan tujuan agar dapat mencapai ketiga hal tersebut.

7) Sapu lidi tiga katih (3 batang): penulis mengambil kesimpulan bahwa makna dari tiga sapu lidi adalah semangat untuk bekerja keras dalam menjalani kehidupan berumah tangga yang didasarkan oleh Tri Kaya Parisudha. Tiga sapu lidi juga bermakna lahir, hidup dan mati.

8) Sambuk (serabut) kupakan: makna dari sambuk/serabut yang dibelah tiga selanjutnya disatukan kembali menggunakan benang Tri Datu adalah bahwa perkawinan merupakan penyatuan dari tiga pihak yang tadinya terpisah yaitu keluarga pria, keluarga wanita dan jiwa kedua pasangan itu sendiri menjadi satu kesatuan keluarga yang utuh. Benang Tri Datu merupakan simbol Brahma, Wisnu dan Iswara yaitu pencipta, pemelihara dan pelebur, itu berarti pasangan baru hendaknya mampu menciptakan, memelihara hal-hal yang baik dan memecahkan masalah melalui akal sehat sehingga terwujud keluarga yang utuh dan harmonis.

9) Dagangan: bermakna adanya sesuatu masalah yang harus didiskusikan sebelum diambil suatu keputusan sehingga kehidupan rumah tangga menjadi harmonis atau sukhinah.

Dengan memahami makna simbol-simbol uparengga pada upacara mekala-kalaan diharapkan umat Hindu etnis Bali khususnya yang lahir dan besar diluar Bali memiliki keyakinan akan pelaksanaan upacara mekala-kalaan sebagai proses mewujudkan rumah tangga yang sukhinah. 


\section{DAFTAR PUSTAKA}

Bogdan, Robert C and Sari Knopp Biklen, 2007. Qualitative for Education An Introduction to Theory and Methods Fifth Edition. New York: Pearson.

Bungin, Burhan. 2010. Penelitian Kualitatif: Komunikasi, Ekonomi, Kebijakan Publik, dan Ilmu Sosial Lainnya. Jakarta: Kencana Prenada Media.

Creswell, John W. 2007. Qualitative Inquiry \& Research Design: Choosing Among Five Approaches. California: Thousand Oaks Sage Publications

Moleong, J. Lexy. 2010. Metodologi Penelitian Kualitatif edisi revisi. Bandung: Remaja Rosdakarya.

Pudja, Gede. 2004. Bhagawad Gītā. Surabaya: Paramita.

Pudja, Gede. dan Tjokorda Rai Sudharta. 2004. Mānava Dharmaśāstra. Surabaya: Paramita.

Radhakrishnan, Sarvepalli. 1953. The Principal Upanisads. London: George Allen \& Unwin LTD Ruskin House, Museum ST.

Stake, Robert E. 2010. Qualitative Research Studying How Things Work. New York: The Guilford Press.

Sugiyono. 2011.Metode Penelitian Kombinasi (Mixed Methods). Bandung: Alfabeta.

Surayin. Ida Ayu Putu. 1992. Melangkah ke arah Persiapan Upacara-upacara Yadnya. Denpasar: Upada Sastra.

Sudarsana, I.B Putu. 2008. Ajaran Agama Hindu Makna Upacara Perkawinan Hindu. Denpasar: Panakom Publishing untuk Yayasan Dharma Acarya.

---------------. 2000. Ajaran Agama Hindu Uparengga Edisi II. Bali: Yayasan Dharma Acarya.

Sudharta, Tjok Rai. 2006. Manusia Hindu dari Kandungan sampai Perkawinan.

Denpasar: Yayasan Dharma Naradha.

Titib, I Made. 1996. Veda Sabda Suci Pedoman Praktis Kehidupan. Surabaya: Paramita.

Titib, I Made. 1996. Perkawinan dan Kehidupan Keluarga menurut Kitab Suci Veda. Surabaya: Paramita

Titib, I Made. 1997. Pedoman Upacara Suddhi Wadani. Denpasar: Upada Sastra. Titib, I Made. 2003. Teologi \& Simbol-simbol dalam Agama Hindu. Surabaya:Paramita.

Triguna, Ida Bagus Gde Yudha. 2000. Teori tentang Simbol. Denpasar: Widya Dharma Universitas Hindu Indonesia. 